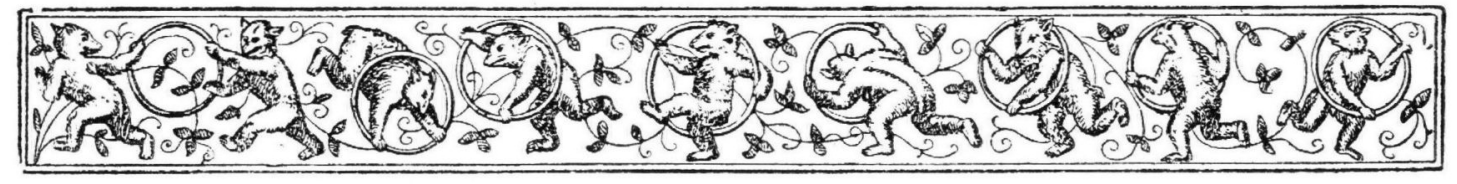

\title{
Ottomar Hackius, een dapper schilder
}

DOOR

\author{
A. BREDIUS.
}

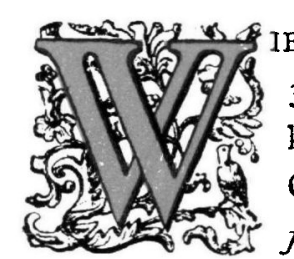

IE heeft ooit een Vanitas van OTTOMARIUS HACKIUS gezien? 3 I Maart 1645 wordt in een Haagschen boedel (bij een wijnkooper) een Vanitas van Hackius op $f$ 40.-, een see van CoRnelis MOLyN op $f$ I5.- en een lantschap van CROOS op JASPERSDR. VAN DEN BROECK: 2 bosschagiens van HACKGES, en een stuck van HACKGES wesende een revier en waterval verciert met beelden. Waarschijnlijk is dit ook HackiUs. Wie is die schilder?

In de zeer inkompleete registers van het Haagsche St. Lucas Gilde komt hij niet voor; alleen op een lijst van jaarlijksche contributies tot onderhoud van het gilde vind ik: OtTomarius Hackius 3 gl. 3 st. ingeschreven I Mei I663. ") Maar reeds 19 Oct. 1650 geeft OtToMaRius HackiUs, schilder in den Hage, iemand een machtiging. ${ }^{2}$ ) Vóór 1655 had hij echter reeds het penseel met het rappier verwisseld. De volgende aardige acte doet ons zien hoe de vendrichschilder toch nog kunstlessen gaf midden onder het krijgsgewoel.

I9 Oct. I655 compareeren d'E. Sr. Ottomarius Hackius, Mr. Schilder en vendrich ten dienste deser landen, in garnisoen tot Rhees, ter eenre, ende Cornelis Cornelisz Proot, jongman, ter andere zijde, en zijn overeengecomen, als volcht: dat d'voorsz. OTTOMARIUS HACKIUs heeft aengenomen, en d'voorn.

1) Obreen's Archief IV.

2) No:. J. TrMMER, den Haag. 
Cornelis Cornelisz. Proot met kennisse van zijnen oom, Sr. Mathias Proot, sich selven heeft besteet en verbonden voor twee en een halff achtereenvolgende jaren, omme bij den voorn. HACKIUs te woonen, en sal densilven HaCkiUs hem PROOT lecren schilderen, hem in cost, clederen enz. onderhouden, en hem soo veel mogelijck in de conste van schilderen instrueren en onderwijsen; ende sal de voorn. HACKIUS daarvoor genyeten geduyrende de voorsz. $2 \frac{1}{2}$ jaren seecker tractement offte soldatenpaye van Ioo glds. s'jaers, als den voorsz. PROOT onder de Compie van $L_{t}$ Cornl. van THIEnEN is treckende. Enz. Oock sal HaCkius genieten de gerechte helfte van alles wat PROOT, niet allecn met schilderen ondertusschen sal mogen winnen, maer oock 't geen hij onder de voorsz. Compie als soldaet sal comen te verdienen. Enz.

\section{Onderteekend: OTTOMARIUS HACKIUS.} Cornelis Proot. ${ }^{1}$ )

Kort daarna werd hij gewond, blijkbaar ernstig. In een ongedateerd klad van een "Request aen de Raden der Groot Mo: Heeren Staten" verzoekt OtTomakius Hackius, Luytenant van Capt Adriaen van Beveres, om na zijn herstel van het vuur in den arm en hevige koortsen weder "ten eersten op „een galjoot of jacht van s'lants vloot" mede te mogen gaan.

2 I April I670 was hij reeds overleden. Iemand blijft dan borg voor MARIA VAN VALEN, Wede en boedelhoudster van OtTomarius HaCkiUs, in syn leven Luytenant ten dienste deser landen. ${ }^{2}$ )

Hij had aanzienlijke familie. 7 Mei 165 I bespreekt SoEtgen CoesaerT, zuster van den bekenden Haarlem'schen burgemeester SALOMON COESAERT in haar Testament voor Not. N. VAN Bosvelt verleden, aan haren "Neeff" OTToMARIUS HACKIUS $f$ 200. - "volgens seeckere Acte daervan bestaende". Maar zij overleed eerst 3 I Dec. I669.

1) Prot. Not. A. v. WArmenhuysen, den Haag.

2) Prot. Not. P. van Roon, den Ha ag.

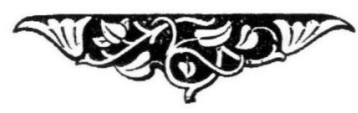

